\title{
Effects of Lactobacillus feed supplementation on cholesterol, fat content and fatty acid composition of the liver, muscle and carcass of broiler chickens
}

\author{
Ramasamy KALAVATHY ${ }^{a * * * *}$, Norhani ABDULlaH ${ }^{\mathrm{b}}$, Syed JALALUDIN $^{\mathrm{c}}$, \\ Michael C.V.L. WONG ${ }^{\mathrm{d}}$, Yin Wan $\mathrm{Ho}^{\mathrm{a}}$
}

\footnotetext{
a Institute of Bioscience, Universiti Putra Malaysia, 43400 UPM, Serdang, Selangor, Malaysia ${ }^{\mathrm{b}}$ Department of Biochemistry and Microbiology, Universiti Putra Malaysia, 43400 UPM, Serdang, Selangor, Malaysia

${ }^{c}$ Department of Animal Science, Universiti Putra Malaysia, 43400 UPM, Serdang, Selangor, Malaysia

d Biotechnology Research Institute, Universiti Malaysia Sabah, 88999 Kota Kinabalu, Sabah
}

(Received 14 June 2004; accepted 2 August 2005)

\begin{abstract}
An experiment was conducted to study the effects of feed supplementation with a mixture of Lactobacillus cultures (LC) on cholesterol, fat and fatty acid composition in the liver, muscle and carcass of broiler chickens. One hundred and thirty-six, one-day-old male broiler chicks (Avian-43) were assigned randomly to two dietary treatments: (i) a basal diet (control), and (ii) a basal diet + $0.1 \%$ LC. The cholesterol contents of the carcass and liver but not the muscle, were significantly $(P<0.05)$ lower in LC-fed broilers. The fat contents of the liver, muscle and carcass were also significantly $(P<0.05)$ lower in the LC-fed broilers when compared to the control broilers. Supplementation of LC in the broiler diets significantly $(P<0.05)$ reduced the oleic acid $\left(\mathrm{C}_{18: 1}\right)$ levels of the liver, muscle and carcass but the arachidonic acid $\left(\mathrm{C}_{20: 4}\right)$ level was significantly $(P<0.05)$ increased in the liver only. Supplementation of $\mathrm{LC}$ also increased the total polyunsaturated fatty acids (PUFA) in the liver. The results of the present study indicate that LC reduces the fat content of the liver, muscle and carcass of broiler chickens, but it has very little potential to modify the fatty acid composition.
\end{abstract}

Lactobacillus / cholesterol / fat / fatty acids / chicken

Résumé - Effets de l'addition de lactobacilles dans l'aliment de poulets de chair sur les teneurs en cholestérol, graisse et acides gras du foie, du muscle et de la carcasse. Une expérience a mesuré les effets de l'addition d'un mélange de cultures de lactobacilles (LC) dans l'aliment de poulets de chair sur la composition en cholestérol, en graisse et en acides gras du foie, du muscle et de la carcasse. Cent trente six poussins mâles de 1 jour (Avian-43) ont été répartis au hasard dans deux lots recevant soit un régime témoin non supplémenté soit le même régime $+0,1 \%$ de LC. Les concentrations en cholestérol de la carcasse et du foie mais pas celles du muscle, étaient significativement $(P<0,05)$ plus faibles chez les poulets consommant LC par rapport aux témoins. La supplémentation de LC

* Corresponding author: kalav922@salam.uitm.edu.my

** Current address: Faculty of Pharmacy, Universiti Teknologi MARA, 40450, Shah Alam, Selangor. 
dans les aliments a réduit significativement $(P<0,05)$ la teneur en acide oléique $\left(\mathrm{C}_{18: 1}\right)$ dans le foie, le muscle et la carcasse mais celle en acide arachidonique $\left(\mathrm{C}_{20: 4}\right)$ n'était significativement augmentée $(P<0,05)$ que dans le foie. La supplémentation en LC a également augmenté la teneur du foie en acides gras polyinsaturés (PUFA). Les résultats de la présente étude suggèrent que $\mathrm{LC}$ réduit la teneur en graisse du foie, du muscle et de la carcasse des poulets de chair mais a une action limitée sur la composition en acides gras.

lactobacille / cholestérol / graisse / acides gras / poulet de chair

\section{INTRODUCTION}

Probiotics or direct-fed microbials are live microbial supplements which beneficially affect the health of the host animal by improving its intestinal microbial balance [8]. In recent times, with the renewal of interest in the use of probiotics, development of more effective probiotic preparations, which comply with the various probiotic characteristics, has been found to improve performance in poultry $[9,11]$. Several of our studies have consistently shown that the growth performances of broilers supplemented with a probiotic containing 12 Lactobacillus cultures are significantly improved [12-14, 24]. The present study was conducted to determine the effects of this Lactobacillus probiotic on cholesterol, fat content and fatty acid composition of the liver, muscle and carcass of broiler chickens.

\section{MATERIALS AND METHODS}

\subsection{Chickens and diets}

One hundred and thirty-six, one-day-old Avian-43 male broiler chicks were obtained from a commercial hatchery. The chicks were weighed individually, wing banded and assigned randomly to two dietary treatments. Each dietary treatment had four replicate cages with 17 chicks per cage and the cages were randomized with respect to the dietary treatments. Each cage $(0.9 \mathrm{~m}$ length $\times 0.6 \mathrm{~m}$ width $\times 0.5 \mathrm{~m}$ height) was provided with a self-feeder and waterer. Feed was provided ad libitum in a mash form throughout the experimental period.
Table I. Composition of the basal diets.

\begin{tabular}{|c|c|c|}
\hline $\begin{array}{l}\text { Ingredient } \\
\left(\mathrm{g} \cdot \mathrm{kg}^{-1} \text { unless otherwise }\right. \\
\text { stated })\end{array}$ & $\begin{array}{c}\text { Starter } \\
(1 \text { to } 21 \mathrm{~d})\end{array}$ & $\begin{array}{l}\text { Grower } \\
22 \text { to } 42 \mathrm{~d})\end{array}$ \\
\hline Ground yellow corn & 538.9 & 603.0 \\
\hline Soyabean meal (44.6\% CP) & 361.9 & 318.6 \\
\hline Fish meal & 30.0 & 30.0 \\
\hline Palm oil & 37.3 & 24.4 \\
\hline $60 \%$ choline chloride & 2.5 & 2.0 \\
\hline Trimix $^{1}$ & 1.0 & 1.0 \\
\hline Salt $(\mathrm{NaCl})$ & 2.0 & 1.0 \\
\hline Antioxidant & 0.125 & 0.125 \\
\hline DL-methionine & 1.775 & 0.375 \\
\hline Limestone & 13.0 & 13.0 \\
\hline Dicalcium phosphate & 11.5 & 6.5 \\
\hline Total & 1000.0 & 1000.0 \\
\hline \multicolumn{3}{|c|}{ Calculated analysis ( $\mathrm{g} \cdot \mathrm{kg}^{-1}$ except energy) } \\
\hline Crude protein & 220.0 & 199.9 \\
\hline Crude fat & 63.1 & 52.2 \\
\hline Crude fibre & 38.0 & 36.5 \\
\hline Calcium & 10.2 & 9.0 \\
\hline Available phosphorus & 4.5 & 3.5 \\
\hline 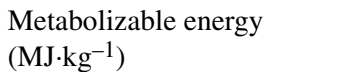 & 13.06 & 13.06 \\
\hline
\end{tabular}

$\overline{1}$ Trimix (per kg Trimix): iron $100 \mathrm{~g}$; manganese $110 \mathrm{~g}$; copper $20 \mathrm{~g}$; zinc $100 \mathrm{~g}$; iodine $2 \mathrm{~g}$; selenite $0.2 \mathrm{~g}$; cobalt $0.6 \mathrm{~g}$; antioxidant (santoquin) $0.6 \mathrm{~g}$; folic acid $0.33 \mathrm{~g}$, thiamin $0.83 \mathrm{~g}$; pyridoxine $1.33 \mathrm{~g}$; biotin $2 \% 0.03 \mathrm{~g}$; riboflavin $2 \mathrm{~g}$; cyanocobalamin $0.03 \mathrm{~g}$; D-calcium pantothenate $3.75 \mathrm{~g}$; niacin $23.3 \mathrm{~g}$; retinol $2000 \mathrm{mg}$; cholecalciferol $25 \mathrm{mg}$; $\alpha$-tocopherol $23000 \mathrm{mg}$ IU.

$\mathrm{CP}=$ crude protein.

The dietary treatments consisted of a basal diet (control) and basal diet $+0.1 \%$ mixture of 12 Lactobacillus cultures (LC). The basal diet (Tab. I) was a corn-soyabean diet formulated to meet nutrient requirements 
[17]. The 12 Lactobacillus cultures (which belong to four species) and the method of preparation as a feed supplement were the same as those described by Jin et al. [10, 12]. The viability of LC was checked biweekly to ensure that the viability of the cultures remained at $1 \times 10^{9}$ viable cells per gram. The viable LC cells were incorporated into the basal diet daily at feeding time. The experiment was carried out for 42 days.

\subsection{Sampling procedure}

At the end of the experiment (42 days of age), eight chickens ( 2 chickens per cage) from each treatment (4 cages) were randomly selected, weighed and sacrificed. The carcasses were opened and the livers and the breast muscles (without skin) were removed and frozen at $-20^{\circ} \mathrm{C}$. The remaining carcasses were eviscerated, weighed, and frozen at $-20^{\circ} \mathrm{C}$ until being used for analyses. The frozen carcasses were thawed for $24 \mathrm{~h}$ at $4^{\circ} \mathrm{C}$ prior to autoclaving. Each carcass was autoclaved for $1 \mathrm{~h} \mathrm{[23],} \mathrm{and} \mathrm{then} \mathrm{homoge-}$ nized in a Waring commercial blender ${ }^{1}$. The homogenate was freeze-dried ${ }^{2}$ to a constant weight and re-ground with a domestic blender ${ }^{3}$ to give a homogenous consistency prior to chemical analysis.

\subsection{Chemical analysis}

Fat, cholesterol and fatty acid composition of the carcass, liver and muscle samples were determined. Fat contents of the carcass, liver and muscle samples were measured by extraction in a Soxhlet apparatus ${ }^{4}$ with petroleum ether [1].

Total lipids were extracted from the carcass (about $1 \mathrm{~g}$ ), liver (about $2 \mathrm{~g}$ ) and muscle (about $4 \mathrm{~g}$ ) with $40 \mathrm{~mL}$ chloroform:methanol $(2: 1, \mathrm{vol} / \mathrm{vol})$ in a $50 \mathrm{~mL}$ ground-glass

\footnotetext{
1 Waring Products Division, New Hartford, Connecticut 06057.

2 Labconco Corporation Kansas City, Missouri 64132.

3 Braun GmbH, Kronberg, Germany.

4 Soxtect System HT1043 Extraction Unit.
}

extraction flask according to the method of Folch et al. [4]. In order to determine the cholesterol content, the lipids were further saponified with ethanolic $\mathrm{KOH}$ to remove the fatty acids. Cholesterol was then extracted with n-hexane and measured using the method of Rudel and Morris [19]. For fatty acid determination, extracted lipids were transmethylated with $\mathrm{BF}_{3}$ and methanolic $\mathrm{KOH}$ [1]. Fatty acid profiles were determined by gas chromatography ${ }^{5}$. Aliquots of $2 \mu \mathrm{L}$ were injected into a fused-silica capillary column $(30 \mathrm{~m} \times 250 \mu \mathrm{m}$, inside diameter $)^{6}$. The injector temperature was programmed at $220^{\circ} \mathrm{C}$ and the detector at $220^{\circ} \mathrm{C}$. The column temperature was set at the range of $100-190{ }^{\circ} \mathrm{C}$ with temperature programming at the rate of $5^{\circ} \mathrm{C} \cdot \mathrm{min}^{-1}$ increments for optimal separation. The identification of peaks was made by comparison with the retention time of the authentic fatty acid methyl ester standard ${ }^{7}$. Quantification was made using an internal standard (heneicosanoic acid; $\left.\mathrm{C}_{21: 0}\right)^{8}$ added to the initial sample prior to transmethylation. An HP Chemstation software ${ }^{9}$ was used to integrate peak areas and fatty acid values were expressed as weight percentages.

\subsection{Statistical analysis}

Treatment effects were compared using analysis of variance and treatment means were separated using the least significance difference. Computation was done by using the SAS program [21].

\section{RESULTS}

The average body weights of the control and LC-fed chickens sampled for the analysis of the body composition were $2195 \mathrm{~g}$ and $2296 \mathrm{~g}$ respectively. The cholesterol contents in the carcass and liver of LC-fed broilers were significantly $(P<0.05)$ reduced

5, 9 Hewlett Packard Co., Wilmington, DE 168081610.

6 Supelco Park, Bellefonte, PA.

7, 8 Sigma-Aldrich, St. Louis, M063178. 
Table II. Effects of Lactobacillus cultures on cholesterol and fat contents of carcass, liver and muscle of broiler chickens at $42 \mathrm{~d}$ of age ${ }^{1}$.

\begin{tabular}{lccc}
\hline & Control & LC & SEM \\
\hline Cholesterol $\left(\mathrm{mg} \cdot 100 \mathrm{~g}^{-1}\right)$ & & \\
Carcass & $103.79^{\mathrm{a}}$ & $90.25^{\mathrm{b}}$ & 3.81 \\
Liver & $276.58^{\mathrm{a}}$ & $225.03^{\mathrm{b}}$ & 10.65 \\
Muscle & $59.48^{\mathrm{a}}$ & $57.38^{\mathrm{a}}$ & 1.55 \\
Fat content (\%) & & & \\
Carcass & $14.06^{\mathrm{a}}$ & $13.29^{\mathrm{b}}$ & 0.18 \\
Liver & $3.50^{\mathrm{a}}$ & $2.88^{\mathrm{b}}$ & 0.09 \\
Muscle & $0.89^{\mathrm{a}}$ & $0.70^{\mathrm{b}}$ & 0.03 \\
\hline
\end{tabular}

Means within a row with no common letters differ significantly $(P<0.05)$.

1 Control=basal diet; LC=basal diet $+0.1 \%$ mixture of 12 Lactobacillus cultures.

by 13 and $19 \%$, respectively, when compared to the control broilers (Tab. II). However, the cholesterol content of the muscle was not affected by the supplementation of LC to the broilers. The fat contents in the carcass, liver and muscle were significantly
$(P<0.05)$ decreased in LC-supplemented broilers as compared to the control broilers (Tab. II). The fat contents in the liver and muscle were not as high as that in the carcass.

The major fatty acid compositions of the total lipids from the carcass, muscle and liver of broilers are presented in Table III. There were significantly $(P<0.05)$ lower levels of oleic acid $\left(\mathrm{C}_{18: 1}\right)$ in the carcass, muscle and liver but significantly $(P<0.05)$ higher levels of arachidonic acid $\left(\mathrm{C}_{20: 4}\right)$ in the liver of the LC-supplemented broilers when compared to the control broilers. Broilers supplemented with LC also had significantly $(P<0.05)$ lower levels of total monounsaturated fatty acids (MUFA) in the carcass and liver than the control birds. However, there were no significant differences in the total saturated fatty acids (SFA) in the carcass, liver and muscle of the control and LC-fed broilers. The level of total polyunsaturated fatty acids (PUFA) was significantly $(P<0.05)$ higher in the liver of broilers supplemented with LC but there were no significant differences in the levels

Table III. Effects of Lactobacillus cultures on the fatty acid composition of carcass, liver and muscle of broiler chickens at $42 \mathrm{~d}$ of age ${ }^{1}$.

\begin{tabular}{|c|c|c|c|c|c|c|c|c|c|}
\hline \multirow[t]{3}{*}{ Fatty acid } & \multicolumn{3}{|c|}{ Carcass } & \multicolumn{3}{|c|}{ Liver } & \multicolumn{3}{|c|}{ Muscle } \\
\hline & Control & $\mathrm{LC}$ & SEM & Control & $\mathrm{LC}$ & SEM & Control & $\mathrm{LC}$ & SEM \\
\hline & \multicolumn{3}{|c|}{ - $\%$ of total fatty acid- } & \multicolumn{3}{|c|}{ — $\%$ of total fatty acid- } & \multicolumn{3}{|c|}{ — $\%$ of total fatty acid- } \\
\hline Myristic acid $\left(\mathrm{C}_{14: 0}\right)$ & 3.13 & 3.27 & 0.07 & 1.50 & 1.53 & 0.21 & 1.69 & 1.93 & 0.07 \\
\hline Palmitic acid $\left(\mathrm{C}_{16: 0}\right)$ & 49.16 & 49.57 & 0.54 & 42.19 & 40.21 & 0.74 & 39.69 & 40.74 & 0.53 \\
\hline Palmitoleic acid $\left(\mathrm{C}_{16: 1}\right)$ & 8.38 & 8.34 & 0.59 & 4.55 & 3.80 & 0.48 & 5.02 & 5.05 & 0.53 \\
\hline Stearic acid $\left(\mathrm{C}_{18: 0}\right)$ & 4.57 & 4.69 & 0.24 & 15.09 & 15.99 & 0.37 & 7.07 & 7.14 & 0.31 \\
\hline Oleic acid $\left(\mathrm{C}_{18: 1}\right)$ & $31.15^{\mathrm{a}}$ & $29.08^{b}$ & 0.59 & $20.38^{\mathrm{a}}$ & $17.36^{\mathrm{b}}$ & 0.72 & $25.42^{\mathrm{a}}$ & $23.14^{\mathrm{b}}$ & 0.55 \\
\hline Linoleic acid $\left(\mathrm{C}_{18: 2}\right)$ & 1.85 & 2.81 & 0.41 & 11.91 & 13.49 & 0.57 & 16.60 & 17.42 & 0.43 \\
\hline Linolenic acid $\left(\mathrm{C}_{18: 3}\right)$ & 0.15 & 0.18 & 0.04 & 0.20 & 0.38 & 0.11 & 0.48 & 0.55 & 0.03 \\
\hline Arachidonic acid $\left(\mathrm{C}_{20: 4}\right)$ & 0.07 & 0.09 & 0.01 & $3.16^{\mathrm{b}}$ & $5.48^{\mathrm{a}}$ & 0.21 & 2.72 & 2.79 & 0.29 \\
\hline$\sum$ SFA & 56.86 & 57.53 & 0.49 & 58.78 & 57.74 & 0.92 & 48.45 & 49.81 & 0.51 \\
\hline$\sum$ MUFA & $39.53^{\mathrm{a}}$ & $37.41^{\mathrm{b}}$ & 0.58 & $24.93^{\mathrm{a}}$ & $21.16^{\mathrm{b}}$ & 1.07 & 30.44 & 28.18 & 0.78 \\
\hline$\sum$ PUFA & 2.07 & 3.08 & 0.40 & $15.27^{\mathrm{b}}$ & $19.35^{\mathrm{a}}$ & 0.83 & 19.32 & 20.20 & 0.58 \\
\hline
\end{tabular}

Means within a row for carcass, liver or muscle, with no common letters differ significantly $(P<0.05)$.

${ }^{1}$ Control $=$ basal diet; LC $=$ basal diet $+0.1 \%$ mixture of 12 Lactobacillus cultures.

$\mathrm{SFA}=$ saturated fatty acids; MUFA = monounsaturated fatty acids; PUFA = polyunsaturated fatty acids. 
of PUFA in the carcass and muscle between the treatments. The lowest level of PUFA was observed in the carcass. The supplementation of LC in broiler diets did not affect the levels of linolenic acid $\left(\mathrm{C}_{18: 3}\right)$ or the saturated fatty acids $\left(\mathrm{C}_{14: 0}, \mathrm{C}_{16: 0}\right.$ and $\left.\mathrm{C}_{18: 0}\right)$ in the liver, muscle and carcass.

\section{DISCUSSION}

In this study, broilers fed LC were found to have lower cholesterol contents in the carcass and liver. This result lends support to the finding of our earlier study in which LC-fed broilers had significantly lower serum cholesterol level than the control broilers [12]. Significant reductions of cholesterol in the liver and carcass of broilers fed Bacillus subtilis have been reported by Santoso et al. [20]. Other workers have also reported reductions of cholesterol in the muscle and liver of lambs fed $L$. acidophilus [16], and in the liver of rats fed a mixture of bacteria and yeast [5]. Based on the studies to date, the mechanism(s) responsible for the cholesterol-lowering effect of probiotics remains unclear, but it has been suggested that the effect could be obtained through retarded cholesterol synthesis and increased degradation of cholesterol [5]. The hepatic synthesis of bile acids from cholesterol is the major route of cholesterol excretion [22]. Certain lactic acid bacteria have the ability to produce bile salt hydrolase enzyme, which deconjugates bile salts [15], resulting in greater fecal excretion of bile acids [2]. To re-establish the enterohepatic circulation of biliary acids, the liver would partition more cholesterol into the bile and less into the bloodstream and this may cause a loss of cholesterol from the tissues [18]. The 12 Lactobacillus cultures (LC) used as a probiotic in the present study have been found to produce bile salt hydrolase and exhibit deconjugating activity of bile salts (unpublished data), which could have contributed to an increase in excretion of cholesterol and reduced cholesterol in chickens.
Supplementation of LC to broilers significantly reduced the fat contents of the liver, muscle and carcass. Santoso et al. [20] also found that supplementation of $B$. subtilis in broiler diets significantly $(P<0.05)$ reduced carcass fat deposition and triglyceride levels in the serum, liver and carcass, and suggested that $B$. subtilis could significantly decrease the activity of acetyl-Co A carboxylase which catalyses the rate-limiting step in fatty acid biosynthesis.

In the present study, supplementation of LC was more effective in reducing the monoenoic acid (oleic acid) than the saturated fatty acids. This suggests that supplementation of LC may reduce the synthesis or absorption of oleic acid. A reduced level of oleic acid has also been observed in the liver of rats fed a mixture of probiotics [7]. Davis and Boogaerts [3] demonstrated that oleic acid is the most potent fatty acid in enhancing triglyceride synthesis in the cells. However, the mechanism by which oleic acid activates the triglyceride secretion remains unclear. Among the different tissues examined, only the liver PUFA was significantly $(P<0.05)$ improved with the supplementation of LC. The increased level of arachidonic acid $\left(\mathrm{C}_{20: 4}\right)$ in LC-fed broilers observed in this study was in agreement with the findings of Fukushima and Nakano [5, 6] and Fukushima et al. [7] in which significant increased levels of arachidonic acid $\left(\mathrm{C}_{20: 4}\right)$ were found in the liver and serum of rats supplemented with a mixture of probiotics. Fukushima et al. [7] suggested that the increased levels of arachidonic acid were due to the $\Delta 6$-desaturase activity in the liver microsomes of the probiotic-fed animals. Supplementation of LC in broiler diets had no significant effects on the fatty acid composition of muscle tissues, with the exception of a significantly $(P<0.05)$ lower level of oleic acid. The change in the composition of fatty acids in muscle tissue lipid was less susceptible than that in the liver or carcass.

In conclusion, the results from the present study demonstrated that LC supplementation 
to broilers reduced the fat contents in the carcass, muscle and liver, and cholesterol in the carcass and liver. Supplementation of LC also increased the total PUFA in the liver but has very little effect on the fatty acid composition of the muscle.

\section{REFERENCES}

[1] Association of Official Analytical Chemists, Official Methods of Analysis: Fat or ether extract in meat, 15th ed., AOAC, Washington, 1990.

[2] Chickai T., Nakao H., Uchida K., Deconjugation of bile acids by human intestinal bacteria implanted in germfree rats, Lipids 22 (1987) 669-974.

[3] Davis R.A. Boogaerts J.R. Intrahepatic assembly of very low density lipoproteins, J. Biol. Chem. 257 (1982) 10908-10913.

[4] Folch J., Lees M., Stanley G.H., A simple method for the isolation and purification of total lipids from animal tissues, J. Biol. Chem. 226 (1957) 497-509.

[5] Fukushima M., Nakano M., The effect of a probiotic on faecal and liver lipid classes in rats, Br. J. Nutr. 73 (1995) 701-710.

[6] Fukushima M., Nakano M., Effects of a mixture of organisms, Lactobacillus acidophilus or Streptococcus faecalis on cholesterol metabolism in rats fed on a fat- and cholesterol-enriched diet, Br. J. Nutr. 76 (1996) 857867.

[7] Fukushima M., Yamada A., Endo T., Nakano M., Effects of a mixture of organisms, Lactobacillus acidophilus or Streptococcus faecalis on $\Delta 6$-desaturase activity in the livers of rats fed a fat- and cholesterol-enriched diet, Nutrition 15 (1999) 373-378.

[8] Fuller R., Probiotics in man and animals, J. Appl. Bacteriol. 66 (1989) 365-378.

[9] Fuller R., Probiotics for farm animals, in: Tannock G.W. (Ed.), Probiotics: A Critical Review, Horizon Scientific Press, Wymondham, England, 1999, pp. 15-22.

[10] Jin L.Z., Ho Y.W., Ali A.M., Abdullah N., Ong K.B., Jalaludin S., Adhesion of Lactobacillus isolates to intestinal epithelial cells of chicken, Lett. Appl. Microbiol. 22 (1996) 229-232.

[11] Jin L.Z., Ho Y.W., Abdullah N., Jalaludin S., Probiotics in poultry: modes of action, World's Poult. Sci. J. 53 (1997) 351-368.

[12] Jin L.Z., Ho Y.W., Abdullah N., Jalaludin S., Growth performance, intestinal microbial populations and serum cholesterol of broilers diets containing Lactobacillus cultures, Poult. Sci. 77 (1998) 1259-1265.

[13] Jin L.Z., Ho Y.W., Abdullah N., Jalaludin S., Digestive and bacterial enzyme activities in broilers fed diets supplemented with Lactobacillus cultures, Poult. Sci. 79 (2000) 886-891.

[14] Kalavathy R., Abdullah N., Jalaludin S., Ho Y.W., Effects of Lactobacillus cultures on growth performance, abdominal fat deposition, serum lipids and weight of organs of broiler chickens, Br. Poult. Sci. 44 (2003) 139-144.

[15] Klaver F.A.M., Van der Meer R., The assumed assimilation of cholesterol by lactobacilli and Bifidobacterium bifidium is due to their bile salt-deconjugating activity, Appl. Environ. Microbiol. 59 (1993) 1120-1124.

[16] Lubbadeh W., Haddadin M.S.Y., Al-Tamimi M.A., Robinson R.K., Effect on the cholesterol content of fresh lamb of supplementing the feed of Awassi ewes and lambs with Lactobacillus acidophilus, Meat Sci. 52 (1999) 381-385.

[17] National Research Council, Nutrient Requirements of Poultry, 8th ed., National Academic Press, Washington, DC, 1984.

[18] Ros E., Intestinal absorption of triglyceride and cholesterol. Dietary and pharmacological inhibition to reduce cardiovascular risk, Atherosclerosis 151 (2000) 357-379.

[19] Rudel L.L., Morris M.D., Determination of cholesterol using o-phthadealdehyde, J. Lipid Res. 14 (1973) 364-366.

[20] Santoso U., Tanaka K., Ohtani S., Effect of dried Bacillus subtilis culture on growth, body composition and hepatic lipogenic enzyme activity in female broiler chicks, Br. J. Nutr. 74 (1995) 523-529.

[21] SAS Institute, SAS ${ }^{\circledR}$ User's Guide: Statistics: Release 6.12. Edition, SAS Institute Inc., Cary, NC, 1997.

[22] Wilson T.A., Nicolosi R.J., Rogers E.J., Sacchiero R., Goldberg D.J., Studies of cholesterol and bile acid metabolism, and early atherogenesis in hamsters fed GT16-239, a novel bile acid sequestrant (BAS), Atherosclerosis 140 (1998) 315-324.

[23] Zubair A.K., Leeson S., Changes in body composition and adipocyte cellularity of male broilers subjected to varying degrees of earlylife feed restriction, Poult. Sci. 75 (1996) 719_ 728.

[24] Zulkifli I., Abdullah N., Azrin M.N., Ho Y.W., Growth performance and immune response of two commercial broiler strains fed diets containing Lactobacillus cultures and oxytetracycline under heat stress conditions, Br. Poult. Sci. 41 (2000) 593-597. 